\title{
PENERAPAN CONTEXTUAL TEACHING AND LEARNING (CTL) PADA PEMBELAJARAN TEMATIK KELAS IV-B MADRASAH IBTIDAIYAH NEGERI 6 JEMBER
}

\author{
ARFAN EFENDI ${ }^{1}$, ABD.MUHITH ${ }^{2}$ \\ ${ }^{1}$ IAIN Jember, Jl. Mataram No.1 Mangli Jember, Jawa Timur Indonesia \\ e-mail: arfanefendi465@gmail.com \\ ${ }^{2}$ IAIN Jember, Jl. Mataram No.1 Mangli Jember, Jawa Timur Indonesia \\ e-mail: abdmuhith1972@gmail.com
}

\begin{abstract}
2013 curriculum is a must thematic learning applied in elementary, this is because the basic thematic learning is explained in Attachment to the Minister of Education Regulation No. 67 of 2013 concerning the Basic Framework and Curriculum Structure of Elementary Schools / Islamic Elementary School that for the learning process at the elementary levels from grade 1 to grade VI uses integrated thematic learning. Thematic learning in application needs to use appropriate methods in its application so that learning objectives can be accepted by students. Learning methods with Contextual Teaching and Learning become an appropriate alternative when paired with thematic learning. The focus of research in this thesis is How is the Implementation of Planning, Implementation and Evaluation of Contextual Teaching and Learning (CTL) in Thematic Learning Class IV-B Islamic Elementary School Negeri 6 Jember Academic Year 2019/2020 ?. This study aims to Explain the Implementation of Contextual Teaching and Learning (CTL) Planning, Implementation in Thematic Learning Class IV-B Islamic Elementary School 6 Jember Academic Year 2019/2020. This study uses a qualitative approach to the type of descriptive research. In determining the research subject using Purposive Sampling and using data collection techniques through observation, interviews and documentation.
\end{abstract}

Keywords: Contextual Teaching and Learning (CTL), Tematik, Islamic Elementary School

Kurikulum 2013 menjadi keharusan pembelajaran tematik diterapkan di SD/MI, hal ini dikarenakan dasar pembelajran tematik dijelaskan dalam Lampiran Permendikbud RI No. 67 Tahun 2013 tentang Kerangka Dasar dan Struktur Kurikulum Sekolah Dasar/ Madrasah Ibtidaiyah bahwa untuk proses pembelajaran pada jenjang SD/MI dari kelas 1 hingga kelas VI menggunakan pembelajaran tematik terpadu. Pembelajaran tematik dalam penerapan perlu menggunakan metode-metode yang tepat dalam penerapannya agar maksud pembelajaran dapat di terima oleh siswa. Metode pembelajaran dengan Contextual Teaching And Learning menjadi alternatif yang tepat bila di padukan dengan pembelajaran tematik. Fokus penelitian dalam skripsi ini adalah Bagaimana Penerapan Perencanaan, Pelaksanaan dan Evaluasi Contextual Teaching and Learning (CTL) pada Pembelajaran Tematik Kelas IV-B Madrasah Ibtidaiyah Negeri 6 Jember Tahun Pelajaran 2019/2020?. Penelitian ini bertujuan untuk Menjelaskan Penerapan Perencanaan, Pelaksanaan dan Evaluasi Contextual Teaching and Learning (CTL) pada Pembelajaran Tematik Kelas IV-B Madrasah Ibtidaiyah Negeri 6 Jember Tahun Pelajaran 2019/2020. Penelitian ini menggunakan pendekatan kualitatif dengan jenis penelitian deskriptif. Dalam penentuan subjek penelitian menggunakan Purposive Sampling serta menggunakan teknik pengumpulan data melalui observasi, wawancara dan dokumentasi.

Kata Kunci: Contextual Teaching and Learning (CTL), Tematik, Madrasah Ibtidaiyah 


\section{PENDAHULUAN}

Pembelajaran merupakan komponen penting dalam membentuk manusia yang memiliki kualitas lebih baik. Peningkatan kualitas tersebut tidak terlepas dari kualitas yang dimiliki tenaga pendidik atau Sumber Daya Manusia (SDM). Oleh sebab itu, lembaga pendidikan juga harus mampu memenuhi kebutuhan SDM baik dalam segi jumlah maupun kualitas guna mengembangkan unsur-unsur pokok serta meningkatkan proses pendidikan setempat.

Peningkatan kualitas pembelajaran perlu menggunakan strategi-strategi tertentu. Strategi tersebut tidak lain adalah pemilihan model, metode dan penggunaan media pembelajaran. Dalam pemilihan dan penggunaan metode pembelajaran tersebut, hendaknya tenaga pendidik memperhatikan kondisi sekolah juga lingkungan disekitar sekolah tersebut. Upaya ini dilakukan agar pemilihan dan penggunaan metode pembelajaran tersebut lebih terarah, tepat dan efisien.

Pembelajaran adalah porses pemberian pengetahuan dari pendidik ke peserta didik, pembelajaran yang baik yaitu apabila sesuai dengan kondisi dari peserta didik, seperti kondisi lingkungan keluarga, kondisi lingkungan sekolah, dan kondisi lingkungan masyarakat. Hal ini juga berpengaruh pada strategi pembelajaran yang digunakan di kelas, seorang pendidik tentunya harus mengetahui tentang strategi-strategi yang tepat dan sesuai untuk diterapkan dalam setiap pembelajaran. Sedangkan menurut Djahiri dalam proses pembelajaran prinsip utamanya adalah adanya proses keterlibatan seluruh atau sebagian besar potensi diri siswa (fisik dan nonfisik) dan kebermaknaannya bagi diri dan kehidupannya saat ini dan di masa yang akan datang (life skill). ${ }^{1}$

Perencanaan pembelajaran yaitu menetapkan tujuan yang akan dicapai, kemudian menetapkan langkah-langkah yang harus dilakukan dalam memcapai tujuan. ${ }^{2}$ Maka dari hal ini seorang guru perlu merencakan suatu program pembelajaran yang sesuai dengan kondisi siswa, dimana siswa perlu membentuk pengetahuannya sendiri dengan bantuan gurunya sebagai pembimbinggnya.

Pendidik (guru) adalah orang yang paling dekat dengan siswa. Untuk mendampingi dalam kegiatan sekolah anak-anak didampingi oleh orang ahli dan mengerti tentang psikologi anak, sehingga memberi kan kesempatan yang sebesar-besarnya kepada anak untuk menciptakan sendiri dunianya melalui berbagai pelajarannya. ${ }^{3}$

\footnotetext{
${ }^{1}$ Djahiri, Kunandar, Guru Profesional, (Jakarta: PT Raja Grafindo Persada, 2007), 287

2 Mukni'ah, Perencanan Pembelajaran, (Jember: IAIN Jember Press, 2016), 5.

${ }^{3}$ Abdullah idi, Sosiologi Pendidikan (Individu Masyarakat, dan Pendidikan), (Jakarta: PT Raja Grafindo Persada, 2011), 23.
} 
Sementara itu, kebijakan bahwa kegiatan pembelajaran di SD/MI harus didasarkan pada Permendikbud No. 32 Tahun 2013 Pasal 19 Ayat (1) yang menyebutkan; "Proses Pembelajaran pada satuan pendidikan diselenggarakan secara interaktif, inspiratif, menyenangkan, menantang, memotivasi peserta didik untuk berpartisipasi aktif, serta memberikan ruang yang cukup bagi prakarsa, kreativitas, dan kemandirian sesuai dengan bakat, minat, dan perkembangan fisik serta psikologis peserta didik". ${ }^{4}$ Pada aspek ini pembelajaran yang sifatnya kontektual memberikan kesempatan pada siswa untuk berfikir bebas tanpa terikat oleh apapun, maka hal ini lebih efektif dalam pembelajaran apabila diterapkan.

Contekstual teaching learning sendiri adalah konsep belajar dimana guru menghadirkan dunia nyata kedalam kelas dan mendorong siswa membuat hubungan antara pengetahuan yang dimiliki dengan penerapan dikehidupan sehari-hari, siswa memperoleh pengetahuan dan keterampilan dalam konteks yang terbatas sedikit demi sedikit, dan dari proses merekonstruksi sendiri, sebagai bekal dalam memecahkan masalah kehidupannnya sebagai anggota masyarakat. ${ }^{5}$

Pembelajaran tematik di MIN 6 Jember menurut Nawawi, sudah dilaksanakan sejak beberapa tahun yang lalu, yang mana siswa dari kelas 1 sampai 6 sudah menerapkannya. ${ }^{6}$ "Pembelajaran tematik adalah pendekatan yang memadukan bebagai mata pelajaran menjadi satu tema. Satu tema ini terdapat beberapa subtema yang masing masing lebih dari empat subtema, dari subtema ini juga di perkecil lagi menjadi beberapa pembelajaran, maka untuk satu tema bisa menghabiskan satu bulan untuk menyelesaikannya, sebagaimana diunkapkan oleh Naely Hanik": ${ }^{2}$

Dasar pembelajran tematik dijelaskan dalam Lampiran Permendikbud RI No. 67 Tahun 2013 tentang Kerangka Dasar dan Struktur Kurikulum Sekolah Dasar/ Madrasah Ibtidaiyah bahwa untuk proses pembelajaran pada jenjang SD/MI dari kelas 1 hingga kelas VI menggunakan pembelajaran tematik terpadu. Pembelajaran tematik terpadu merupakan pendekatan pembelajaran yang memadukan berbagai kompetensi dari berbagai mata pelajaran ke dalam berbagai tema. ${ }^{8}$ Menurut Ridwan Abdullah Sani, pengembangan Kurikulum 2013 merupakan upaya peningkatan mutu pendidikan untuk menghasilkan lulusan yang kreatif dan mampu menghadapi kehidupan di masa yang akan datang. ${ }^{9}$

\footnotetext{
${ }^{4}$ PP No No. 32 Tahun 2013, Kegiatan Pembelajaran di SD/MI.

${ }^{5}$ Jumanta hamdayana, Model dan metode pembelajaran Kreatif dan Berkarakter, (Bogor: Ghalia Indonesia, 2017), 53.

${ }^{6}$ Nawawi, Wawancara, Tanggul Jember, Oktober 2018

${ }^{7}$ Naely Hanik, wawancara, Tanggul Jember, Oktober 2018

${ }^{8}$ Abdul Madjid, Pembelajaran Tematik-Terpadu. (Bandung: Remaja Rosdakarya, 2014), 49

${ }^{9}$ Ridwan Abdullah Sani, Inovasi Pembelajaran. (Jakarta: Bumi Aksara, 2013), 7-8
} 
Berdasarkan uraian diatas tersebut, maka penelitian ini adalah "Penerapan Contextual Teaching And Learning (CTL) Pada Pembelajaran Tematik Kelas IV-B Madrasah Ibtidaiyah Negeri 6 Jember Tahun Pelajaran 2019/2020".

\section{TUJUAN}

Berdasarkan fokus penelitian di atas, maka tujuan penelitian ini adalah Untuk mendeskripsikan Penerapan Perencanaan, Pelaksanaan dan Evaluasi Contextual Teaching and Learning (CTL) pada Pembelajaran Tematik Kelas IV-B Madrasah Ibtidaiyah Negeri 6 Jember Tahun Pelajaran 2019/2020.

\section{METODE}

Pendekatan yang digunakan dalam penelitian ini adalah pendekatan kualitatif, karena pendekatan penelitian kualitatif digunakan untuk meneliti obyek yang alamiah, (sebagai lawan dari eksperimen) dimana peneliti adalah sebagai intrumen kunci dan hasil penelitian kualitatif lebih menekankan makna dari pada generalisasi. ${ }^{10}$ Jenis penelitian yang digunakan dalam penelitian ini merupakan penelitian lapangan "field research" ide pentingnya adalah bahwa peneliti berangkat ke lapangan untuk mengadadakan pengamatan tentang sesuatu fenomena dalam suatu keadan. Peneliti lapangan biasanya membuat catatan lapangan secara ekstensif yang kemudian dibuatkan kodenya dan dianalisis dalam berbagai cara. ${ }^{11}$ Teknik pemngumpulan data dari penelitian ini adalah menggunakan triangulasi teknik yaitu dengan observasi, wawancara, dan dokumentasi yang mendukung penelitian ini. Keabsahan data yang digunakan peneliti yaitu menggunakan triangulasi teknik yang terdiri dari observasi, wawancara dan dokumentasi dan triangulasi sumber penelitian ini adalah data dari sekolah, dokumentasi dan kepustakaan.

\section{HASIL DAN PEMBAHASAN}

Berdasarkan hasil penelitian yang dilakukan, peneliti menyajikan mengenai penerapan Contextual Teaching and Learning (CTL) pada pembelajaran Tematik kelas IV-B MIN 6 Jember sebagai berikut.

1. Penerapan Perencanaan Contextual Teaching and Learning (CTL) pada pembelajaran Tematik kelas IV-B MIN 6 Jember Tahun Pelajaran 2019/2020.

Perencanaan Penerapan Contextual Teaching and Learning (CTL) pada pembelajaran Tematik kelas IV-B MIN 6 Jember Tahun Pelajaran 2019/2020. Pembelajaran di Madrasah

\footnotetext{
${ }^{10}$ Sugiyono, Metode Penelitian Kualitatif, (Bandung: Alfabeta, 2017), 9.

${ }^{11}$ Lexy J, Moleong, Metode Penelitian Kualitatif, (Bandung: Remaja Rosdakarya, 2017), 26.
} 
Ibtidayah Negeri 6 Jember diharuskan seorang guru kelas membuat perencanaan pembelajaran (RPP) yang sesuai dengan materi pembelajaran tematik, membuat perencanaan pembelajaran merupakan hal yang sangat penting untuk mempersiapkan proses kegiatan pembelajaran. Perencanaan juga merupakan proses penyusunan materi pelajaran, penggunaan media pembelajaran, penggunaan strategi atau metode, dan penentuan alokasi waktu yang akan dilaksanakan sebelum mengajar di kelas. ${ }^{12}$

Dalam pembuatan Rencana Pelaksanaan Pembelajaran sangat memperhatikan segala point-pointnya, terutama dalam pemilihan strategi pembelajaran dan media pembelajaran yang digunakan. Hal ini sesuai dengan wawancara yang dilakukan peneliti dengan Ibu Kholifah sebagai berikut:

"Saya dalam penyusunan RPP sangat memaksimalkan dalam pemilihan strategi dan media pembelajaran yang akan saya pakai untuk mengajar supaya siswa memahami dan mudah mempraktekkannya, siswa aktif dan senang dalam mengikuti pelajaran saya dan juga supaya tujuan pada setiap pembelajaran yang dilaksanakan tercapai. Dengan ini dalam RPP saya menggunakan CTL dalam pelajaran tematik"13

Hal ini di perkuat dengan adanya rencana pelaksanaan pembelajaran (RPP) tematik di kelas IV-B MIN 6 Jember :
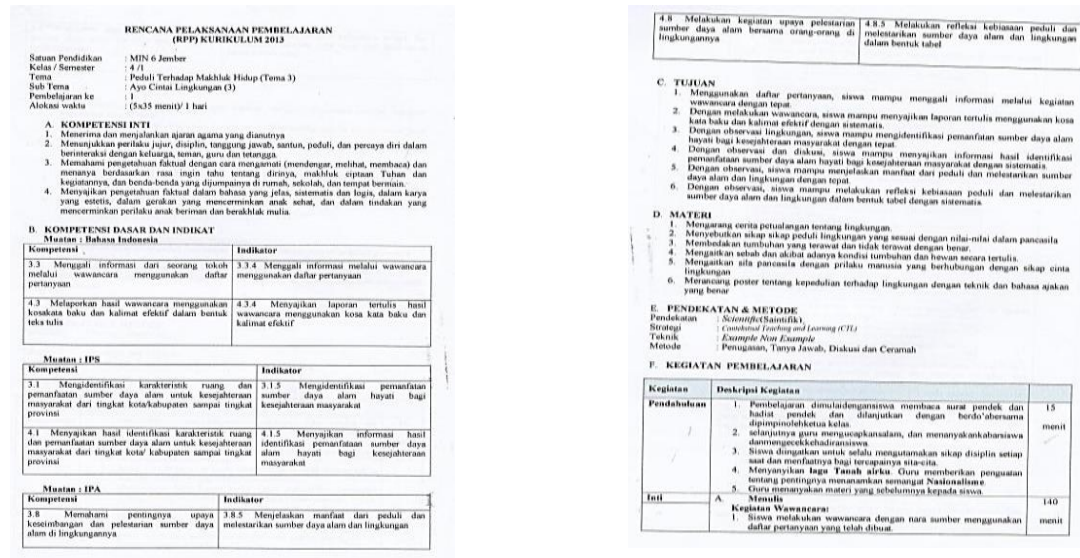

Sehubungan dengan uraian di atas dalam perencanaan penerapan CTL dalam pembelajaran Tematik kelas IV-B di Madrasah Ibtidaiyah Negeri 6 Jember Tahun Pelajaran 2019/2020, berdasarkan pertanyaan peneliti, berikut adalah penjelasan dari Ibu Kholifah selaku guru kelas IV-B menjelaskan bahwa :

"Kontekstual itu dengan menghubungkan materi dengan dunia nyata/kehidupan sehari-hari, baik dalam praktek anak-anak, kerjasama/diskusi, dengan menggunakan berbagai sumber belajar. Contohnya, kemarin saya suruh anak-anak buat kipaskipasan dari kertas. Ini yang dinamakan kontektkstual anak membuat sendiri dan

${ }^{12}$ Observasi, 25 Juli 2019

${ }^{13}$ Kholifah, Wawancara, Jember, 25 Juli 2019 
mempraktekkannya sendiri, jadi penerapan kontektual ini pada tematik lebih cepat paham anak-anak pada pelajaran". ${ }^{14}$

Hal ini diperkuat dengan hasil dokumentasi dari perencanaan pembelajaran tematik tentang pembuatan kipas-kipasan kertas:

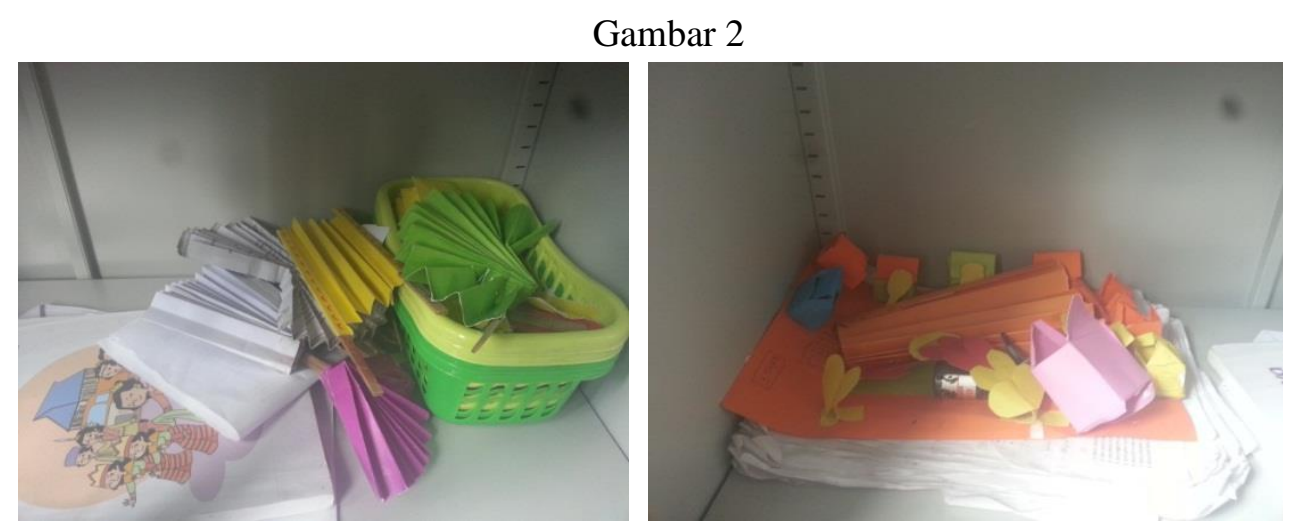

Hasil Karya siswa

Dari hasil observasi dan dokumentasi peneliti rencana pelaksanaan pembelajaran (RPP), dalam pemilihan strategi yang dilakukan guru kelas IV-B MIN 6 Jember ketika dalam pembelajaran memanfaatkan lingkungan sekitar dan pembelajaran yang menghubungkan dengan dunia nyata siswa, Ibu Kholifah menggunakan strategi yaitu Contextual Teaching and Learning (CTL) dan ketika membuat perencanaan pembelajaran untuk melaksanakan pembelajaran. Konsep belajar yang membantu guru mengaitkan antara materi yang diajarkan dengan situasi dunia nyata siswa dan mendorong siswa membuat hubungan antara pengetahuan yang dimilikinya dengan penerapannya dalam kehidupan mereka dapat memberikan suasana inovatif dengan tetap terarah kepada tujuan pembelajaran. Ibu Kholifah sebagai guru Tematik kelas IV-B melakukan upaya tersebut supaya meningkatkan kualitas dan pengembangan kemampuan untuk memanfaatkan media. Tercapainya tujuan pembelajaran juga harus dirasakan oleh siswa juga membuat siswa mampu menerima penjelasan guru dengan menggunakan strategi yang dipakai. Siswa juga merasa senang dengan pembelajaran tematik ini. ${ }^{15}$

Penjelasan diatas di perkuat oleh Ibu Yusnia guru kelas II-B MIN 6 Jember, mengatakan bahwa:

"dalam pembelajaran tematik itu terdapat banyak materi pelajaran, jadi memang kalau saya menggunakan metode CTL dalam pembelajaran, karena memang pembelajaran CTL itu siswa bisa praktek, atau juga kadang belajar di luar kelas. Apalagi siswa kelas 2 itu butuh bimbingan yang ekstra, jadi pelajarannya yang buat siswa senang". ${ }^{16}$

\footnotetext{
${ }^{14}$ Kholifah, Wawancara,Jember, 25 Juli 2019.

${ }^{15}$ Observasi, 25 Juli 2019

${ }^{16}$ Yusnia,Wawancara, Jember, 1 Agustus 2019.
} 
Dari hasil wawancara, observasi, dan kajian dokumen yang dilakukan oleh peneliti didapatkan data bahwa proses perencanaan penerapan Contextual Teaching and Learning (CTL) pada pembelajaran tematik kelas IV-B, dengan demikian meliputi a.) Menyiapkan Rencana Pelaksanaan Pembelajaran (RPP) yang disusun bersama guru kelas dan disetujui oleh kepala Madrasah. b) Menentukan strategi pembelajaran yang dituangkan dalam Rencana Pelaksanaan Pembelajaran. c) Memilih media pembelajaran yang dituangkan dalam rencana pelaksanaan pembelajaran.

Berdasarkan temuan-temuan yang ada di madrasah tersebut bahwa penerapan perencanaan Contextual Teaching and Learning (CTL) pada pembelajaran Tematik kelas IV-B MIN 6 Jember yaitu pertama, guru lebih mudah dalam perencanaan mata pelajaran tematik, kita mengetahui bahwa mata pelajaran tematik itu terdiri dari beberapa mata pelajaran yang dijadikan tema dalam setiap kelasnya, pelajaran tematik terdapat banyak materi pelajaran yang bisa di pelajari dengan keadaan yang ada pada saat itu atau bisa juga di sebut dengan keadaan dunia nyata. Penggunaan strategi CTL dapat di aplikasiakan di dalam pembelajaran, Maka dapat disimpulkan peneliti bahwa membuat perencanaan pembelajaran dengan mengguanakan strategi CTL membantu guru dalam mengaitkan materi dengan dunia nyata dalam membuat perencanaan pembelajaran, oleh karena itu seorang guru agar mudah dalam menyampaikan materi serta mengaitkannya ke dalam dunia nyata, guru juga harus terlebih dahulu mempelajari penerapan strategi CTL pada pelajaran ilmu pengetahuan sosial dengan maksud agar pemahaman siswa terhadap pelajaran akan lebih cepat. Dalam pembelajaran kontekstual guru bukan lagi seorang yang bersifat diktaktor, akan tetapi guru hanya sebagai pemfasilitasi bagi anak didiknya sekaligus sebagai pendamping dalam pencapaian kompetensi dengan cara yang menarik dan menyenangkan. Siswa akan berusaha untuk mencapai tujuan pembelajaran dengan pengalaman serta pengetahuan sebelumnya untuk mendapatkan pengetahuan baru, dengan pengalaman yang baru tersebut siswa supaya mampu menyelesaikan permasalahan yang ada di dunia nyata ini yang begitu kompleks.

Temuan tersebut kemudian didialogkan dengan teori yang dikemukakan oleh Jumanta hamdayana bahwa Pendekatan Contextual Teaching Learning (CTL) merupakan konsep belajar yang membantu guru mengaitkan antara materi yang diajarkan dengan situasi dunia nyata siswa dan mendorong siswa membuat hubungan antara pengetahuan yang dimilikinya dengan penerapannya dalam kehidupan mereka sebagai anggota keluarga dan masyarakat. Dengan pemahaman guru dalam membuat perencanaan ini, hasil belajar diharapkan lebih bermakna bagi siswa. Proses pembelajaran juga berlangsung alamiah, siswa bekerja dan mengalami bukan transfer pengetahuan dari guru ke siswa. 
Kedua. Memberikan motivasi, pembelajaran tematik yang terdiri dari beberapa mata pelajaran tentunya terdapat beberapa pelajaran penting, seperti pelajaran sejarah, atau atau asal usul sebuah tempat, contohnya cerita maling kundang, cerita si baik dan si jahat, dan cerita-cerita lainnya. Dengan adanya cerita ini guru lebih mudah dalam membuat perencanaan pembelajaran, dikarenakan pemberian materi pelajaran yang sesuai dengan kondisi siswa memudahkan guru dalam membuat perencanaan pembelajaran, cerita-cerita seperti ini diharapkan dapat memberikan motivasi bagi siswa untuk meniru pesan - pesan yang baik dalam cerita tersebut, sehingga guru juga mudah memberikan pelajaran bagi siswa, dan siswa lebih mudah memahami pelajaran tematik dengan strategi CTL ini. Namun yang paling penting dari strategi CTL ini seorang guru harus juga memperliatkan sikap dan tingkah laku yang baik bagi siswa, agar siswa dapat meniru. Karena biasanya siswa meniru apa yang dia liat baik dari orang yang terdekat.

Temuan tersebut kemudian dijelaskan dengan teori yang dikemukakan oleh Aris Sholihin yaitu Contextual teaching learning merupakan suatu proses pembelajaran yang holistik bertujuan memotivasi siswa untuk memahami makna materi pelajaran yang dipelajarinya dengan mengaitkan materi tersebut dengan konteks kehidupan sehari-hari (konteks pribadi, sosial, dan kultur) sehingga siswa memiliki pengetahuan/keterampilan yang secara fleksibel dapat diterapkan (ditranfer) dari satu permasalahan ke permasalahan lainnya.

Berdasarkan temuan yang telah didialogkan dengan teori tersebut dapat disimpulkan bahwa penerapan perencanaan Contextual Teaching and Learning (CTL) pada pembelajaran Tematik kelas IV-B MIN 6 Jember memiliki ciri khas tersendiri yaitu dalam pembelajaran guru mengaitkan pelajaran dengan realitas sosial yang ada di lingkungan MIN 6 Jember dengan membuat perencanaan yang sesuai dengan kondisi siswa. Strategi pembelajaran dengan kontekstual ini lebih bermakna terhadap siswa, karena siswa tidak hanya mengetahui konsep atau materi pelajaran melaikan juga mengalaminya atau melakukannya. Sehingga siswa bisa dengan memahami pelajaran yang diberikan oleh guru.

\section{Penerapan Pelaksanaan Contextual Teaching and Learning (CTL) pada pembelajaran} Tematik kelas IV-B MIN 6 Jember Tahun Pelajaran 2019/2020.

Pelaksanaan Penerapan Contextual Teaching and Learning (CTL) pada pembelajaran Tematik kelas IV-B MIN 6 Jember Tahun Pelajaran 2019/2020. Pembuatan perangkat pembelajaran ini sangat penting dan harus dibuat oleh setiap guru kelas. Juga dalam hal pelaksanaan pembelajaran ini guru harus mengikuti langkah-langkah kegiatan yang sudah ada pada rencana pelaksanaan pembelajaran. sehingga kegiatan proses belajar mengajar yang telah direncanakan sebelumnya agar tercapainya tujuan. Kegiatan proses 
pelaksanaan belajar mengajar ini sebagai unsur aktifitas pembelajaran sesuai langkahlangkah yang sudah ada pada rencana pelaksanaan pembelajaran. sehingga akan terlaksana dengan baik dan maksimal.

Pada langkah-langkah kegiatan pelaksanaan pembelajaran dengan kegiatan yang ditempuh ke dalam tiga langkah-langkah sebagai berikut:

a. Kegiatan Awal/Pembukaan

Dalam kegiatan awal/pembukaan ini bahwa guru harus menciptakan suasana belajar yang kondusif agar siswa bisa memusatkan konsentrasi mereka terhadap kegiatan dalam proses belajar. Sehingga siswa juga semangat dalam mempersiapkan materi akan dipelajari. Karena tahap awal/pembukaan ini sebagai pemanasan kepada siswa dalam pembelajaran tematik. Tetapi, pada tahap ini guru tidak hanya bisa mengondisikan siswa seperti duduk rapi, tidak ramai, atau pada saat guru menjelaskan materi siswa tidak mendengarkan. Jadi pada tahap ini guru menggali materi dan memancing siswa mengenai tema yang dipelajari pada hari itu. Agar siswa bisa memahami tema yang akan dipelajarinya dan memikirkan untuk mencari jawaban sendiri, tema apa yang akan dipelajari sekarang.

Pada kegiatan pelaksanaan pada hari itu peneliti mengobservasi kelas IV-B tentang tema Peduli terhadap makhluk hidup dengan subtema ayo cintai lingkungan pada pembelajaran ke-1. Kegiatan awal yang dilakukan oleh guru adalah guru menyuruh siswa membaca surat pendek dan dilanjutkn dengan doa bersama dipimpin oleh ketua kelas. Selanjutnya guru mengucapkan salam dan menanyakan kabar siswa dan mengecek kehadiran siswa, serta siswa bersama-sama menyanyikan lagu Tanah Airku.

Hal ini diperkuat dengan hasil dokumentasi dari kegiatan awal pembelajaran:

\section{Gambar 3}

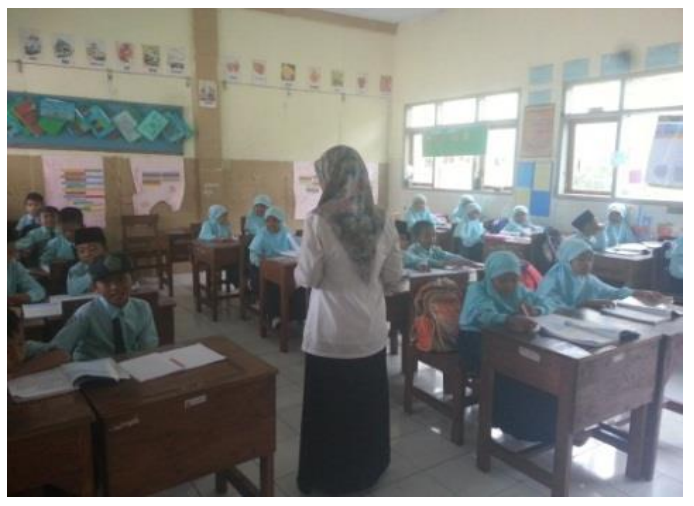

Gambar. Guru memulai pelajaran

a. Kegiatan Inti 
Kegiatan inti yaitu kagiatan pokok dalam pembelajaran, dimana guru harus memfokuskan siswa dalam kegiatan proses belajar. Agar tercapainya tujuan pembelajaran yang efektif dan efesien. setelah tahapan kegiatan awal/pembukaan dilaksanakan.

Hal ini dinyatakan langsung oleh Kepala Madrasah Nawawi, mengatakan:

Pada tahapan kegiatan itu guru memberikan penjelasan terlebih dahulu, setelah itu diberi tugas dan membiarkan, siswa itu yang mencai jawaban itu sendiri. Karena kurikulumnya sudah K13 berbasis tematik maka siswa itu sering dibagi kelompok untuk menmyelesaikan masalah pada saat itu. Dan belajar untuk mencari jawaban sendiri. Jadi guru itu hanya sebagai fasilitator saja. Jadi yang lebih banyak berperan itu siswanya. ${ }^{17}$

Senada dengan hasil wawancara yang dinyatakan oleh Waka Kurikulum Dedi Ependi, menguraikan:

Kegiatan inti pembelajaran itu bukan hanya didalam kelas, tetapi diluar kelas sesuai dengan materi yang akan dipelajari pada pertemanya, contohnya seperti strategi CTL, CTL adalah metode pembejaran tentang memotivasi anak, guru memberikan pembelajaran secara langsung pada siswa. Biasanya siswa di suruh membuat praktek-praktek dalam pembelajaran, misalnya membuat layang-layang, gantungan kelas, dan lain - lain. Jadi siswa dapat tau prosesnya dan bisa menggunakannya, namun perlu diketahui juga penerapan CTL antara kelas bawah dengan atas harus bisa guru dalam menyuasaikannya. Misalnya untuk kelas 1-3 itu tidak ada hukuman, namun beda dengan kelas 4-6 itu sudah diberikan hukuman apabila ada siswa tidak menuruti gurunya". ${ }^{18}$

Kegiatan inti ini guru menyuruh siswa melakukan wawancara dengan narasumber menggunakan daftar pertanyaan yang telah di buatnya sendiri. Tujuan ini agar siswa dapat menggali pengetahuan dari narasumbernya tentang informasi, dan juga untuk melatih kepekaan bahasa indonesianya apabila berbicara dengan temannya.

Dari penjelasan diatas diperkuat dengan dokumentasi dari daftar pertanyaan yang di buat siswa kelas IV-B

\section{Gambar 4}

${ }^{17}$ Nawawi, wawancara, 25 Juli 2019

${ }^{18}$ Dedi Ependi,Wawancara, Jember,

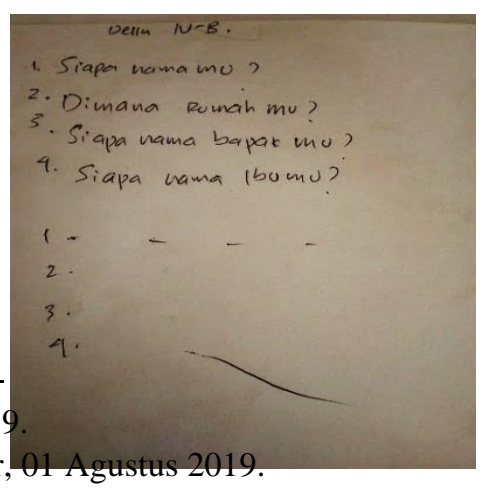


Setelah itu guru menyuruh siswa membaca teks yang tersedia tentang seorang tokoh peduli lingkungan, guru memberikan penguatan dan penjelasan lagi pada siswa.

Mencintai lingkungan dapat dilakukan dengan cara sederhana, seperti : membuang sampah pada tempatnya, menghemat penggunaan kertas, merawat tumbuhan dan hewan yang ada di rumah, dan menjaga hewan dan tumbuhan dimanapun kita berada, seperti tidak memetik daun, bunga, bakal buah, tanpa tujuan. Dengan melakukan kebiasaan-kebiasaan tersebut dalam keseharian, tentunya lingkungan akan terawat dan terjaga kelestariannya. ${ }^{19}$

Pada kegiatan selanjutnya guru menyuruh siswa mengamati gambar hewan dan tumbuhna yang ada di buku. Setelah itu siswa mengamati hewan dan tumbuhan yang terawat dan yang tidak terawat. Siswa memberikan centang pada hewan dan tumbuhan yang terawat.

Dari penjelasan diatas diperkuat dengan dokumentasi dari LKS siswa tentang hewan dan tumbuhan terawat/ tidak terawatt

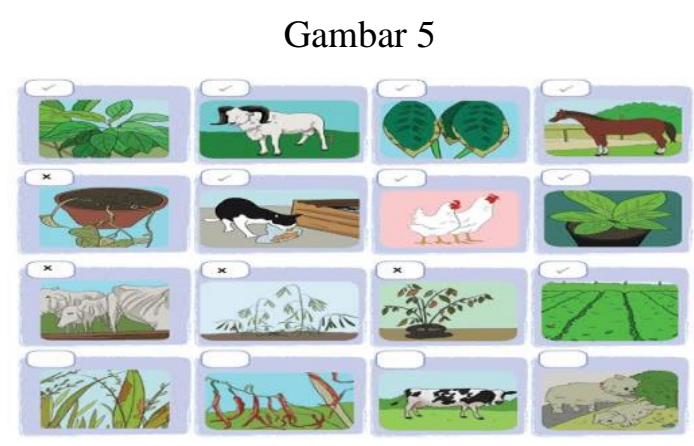

setelah itu guru membagi siswa menjadi 5 kelompok, siswa di suruh membuat rencana peduli lingkungan, siswa dapat menanam sebuah satu jenis tumbuhan di pot, atau di halaman sekolah, setelah itu siswa secara mandiri menyiapkan alat dan bahan yang diperlukan.

Dari hal tersebut di atas bahwa tahap kegiatan inti menyesuaikan tema. Jadi siswa itu memecahkan masalah sesuai dengan temanya yang dipelajari pada hari itu. Tanpa bantuan dari guru tersebut. Dari situ siswa belajar untuk menjelaskan jawaban atau hasil dari yang mereka temui. Jadi siswa itu akan lebih aktif didalam kelas.

Sesuai dengan apa yang sudah paparkan oleh guru-guru, hal ini akan diperkuat oleh sunan

\footnotetext{
${ }^{19}$ Sumber, RPP kelas IV-B MIN 6 Jember
} 
selaku kelas IV-B yang mengatakan:

Iya kalau kegiatan belajar itu ya dari siswa itu biasanya guru menjelaskan sebentar, $\mathrm{Bu}$ guru sering memberikan tugas, seperti praktek, diskusi, belajar di luar kelas. Kalau ada anak yang tidak mau mengerjakan tugas biasanya di nasehati, dan disuruh langsung mengerjakan atau suruh buat PR". ${ }^{20}$

\section{b. Kegiatan Akhir}

Kegiatan akhir/penutup merupakan suatu kegiatan untuk mengakhiri segala aktifitas yang sudah terjadi dalam proses pembelajaran yang dilakukan dalam bentuk memberikan kesimpulan. Jadi dalam menarik kesimpulan itu siswa yang akan menyimpulkan sendiri dari hasil proses pelajaran yang sudah dipelajari. Dengan itu guru akan mengetahui tingkat keberhasilan siswa serta keberhasilan guru dalam pelaksanaan proses belajar mengajar.

Hal ini dinyatakan langsung oleh Kepala Madrasah Nawawi memaparkan:

Pada tahap terakhir yaitu tahap kegiatan akhir/penutup dimana guru itu mengakhiri pelajaran. Untuk memberikan gambaran keseluruhan dan meninjau kembali dengan mengadakan evaluasi pada akhir pembelajaran. sehingga siswa bisa menyimpulkan sendiri dengan apa yang sudah siswa ikuti selama proses belajar berlangsung. ${ }^{21}$

Demikian dengan tahapan kegiatan akhir guru bersama-sama dengan siswa membuat kesimpulan tentang materi yang diajarkan bersama-sama, selanjutnya guru menyampaikan rencana pembelajaran pada pertemuan berikutnya, guru juga memberikan saran dan motivasi belajar kepada siswa. Setelah itu mengakhiri kegiatan pembelajaran dengan doa dan salam.

Berdasarkan temuan-temuan yang peneliti yang dilakukan di Madrasah tersebut bahwa penerapan pelaksanaan Contextual Teaching and Learning (CTL) yang dilaksanakan di MIN 6 Jember sudah baik.

Pembelajaran berbasis praktek, ataupun pembelajaran yang konteks (nyata) yang di terapkan guru dalam setiap pembelajaran tematik. Strategi CTL memudahkan guru dalam memberikan materi kepada siswa sehingga siswa dan guru dapat saling integratif dalam pembelajaran, sehingga siswa tidak hanya mengetahui konsepnya saja melaikan dengan praktek dan penerapannya. Hal ini yang menjadi alasan guru kelas IV-B menerapakan strategi CTL dalam pelaksanaan pembelajaran tematik. Pertama yaitu pemberian tugas, pemberian tugas ini di maksudkan agar siswa bisa mempraktekkan isi dari materi pelajaran tematik, misalnya tugas membuat mobil-mobilan dari kardus dan lain-lainnya, hal ini di maksudkan untuk melatih keterampilan siswa. Sehingga siswa dapat memahami materinya.

\footnotetext{
${ }^{20}$ Sunan, Wawancara, Jember, 25 Juli 2019.

${ }^{21}$ Nawawi, wawancara, Jember, 25 Juli2019.
} 
Temuan tersebut kemudian dijelaskankan dengan teori yang dikemukakan oleh Cucu Suhana yaitu Pembelajaran yang memperkenalkan peserta didik untuk bekerja mandiri dalam mengkonstruk pembelajarannya (pengetahuan dan keterampilan baru), dan mengkulminasikannya dalam produk nyata.

Kedua, yaitu siswa dapat mengkomunikasikan/ membentuk jejaring dalam pembelajaran, biasanya guru IV-B memberikan suatu tugas kelompok pada siswa, bisa berbentuk diskusi, atau tugas praktek keterampilan. Hal ini menjadikan siswa berinteraksi dengan temannya, sehingga terjalin komunikasi yang baik antar siswa.

Temuan tersebut kemudian dijelaskankan dengan teori yang dikemukakan oleh Cucu Suhana yaitu Membentuk jejaring yang dimakudkan sama dengan pembelajaran kolaboratif, pada pembelajaran ini kewenangan guru dan fungsinya lebih bersifat direktif atau manager belajar, sebaliknya siswa yang harus lebih aktif. Jika pembelajaran kolaboratif ini diposisikan sebagai salah satu falsafah pribadi, maka ia akan menyentuh tentang identitas peserta didik terutama jika mereka berhubungan atau berinteraksi dengan yang lain atau guru. dalam situasi ini, siswa akan berinteraksi dengan empati, saling menghormati, dan menerima kekurangan atau kelebihan masing-masing. Dengan cara semacam ini akan tumbuh rasa aman, sehingga memungkinkan peserta didik menghadapi aneka perubahan dan tuntutan belajar secara bersama-sama.

Berdasarkan temuan yang telah dijelaskan dengan teori tersebut dapat disimpulkan bahwa penerapan pelaksanaan Contextual Teaching and Learning (CTL) pada pembelajaran tematik kelas IV-B yaitu dalam proses pembelajaran di kelas IV-B terdapat beberapa startegipembelajaran, dari sakian banyaknya strategi pembelajaran guru di kelas IV-B harus bisa menerapakan strategi- strategi yang tepat di terapakan dalam pelajaran. strategi menentukan keberhasilan pembelajarn, yang mana menjadi jalan proses siswa. Dalam pembelajaran tematik di kela IV-B sendiri yang sudah diterapkan sejak 2015 yang lalu, dan hasil penelitian yang saya lakukan guru kelas IV-B menerapakan strategi CTL (Contextual Teaching and Learning) dijadikan alternatif solusi dalam pembelajaran tematik, peneliti dapat mengamati dari proses belajar siswa, dan dari hasil dari penerapan CTL di kelas IV-B.

\section{Penerapan Evaluasi Contextual Teaching and Learning (CTL) pada pembelajaran} Tematik kelas IV-B MIN 6 Jember Tahun Pelajaran 2019/2020.

Evaluasi Penerapan Contextual Teaching and Learning (CTL) pada pembelajaran Tematik kelas IV-B MIN 6 Jember Tahun Pelajaran 2019/2020. Dari data yang diperoleh dilapangan evaluasi yang dilakukan oleh guru di MIN 6 Jember yaitu menggunakan penilaian autentik dan juga menggambil dari buku guru. Berhubung di MIN 6 Jember 
berbudaya religi jadi penilaian mengenai akhlak juga dinilai oleh guru. Sesuai dengan teori evaluasi autentik pada pembelajaran tematik meiputi:

a. Penilaian Proyek

Proyek bentuk penilaian autentik yang berupa pemberian tugas kepada siswa secara berkelompok. Penilaian proyek dilakukan oleh pendidik untuk tiap akhir bab atau tema pelajaran. ${ }^{22}$

Di MIN 6 Jember semua kelas menggunakan penialain autentik dengan tugas kelompok yang harus diselesaikan oleh siswa. Jadi guru menilainnya pada proses pembelajaran. yang meliputi keterampilan, sesuaian atau relevansi materi pembelajaran dengan pengembangan sikap, keterampilan, dan pengetahuan. Jadi setiap siswa mengerjakan tugas berkelompok guru menilainya dari proses pekerjaannya.

b. Penilaian Kinerja

Pada penilaian kinerja guru dapat melakukannya dengan meminta para peserta didik menyebutnya unsur-unsur proyek/tugas yang akan mereka gunakan untuk menentukkan kriteria penyelesainnnya. Dan juga guru dapat memberikan umpan balik terhadap kinerja peserta didik, baik dalam bentuk laporan naratif maupun laporan kelas. Pengamatan atas kinerja peserta didik perlu dilakukan dalam berbagai konteks untuk menetapkan tingkat pencpaian kemampuan tertentu. ${ }^{23}$

Jadi di MIN 6 Jember guru menilainya dengan menggunakan penilain kinerja. Pada penilaian kinerja yaitu berupa penilaian diri disini guru menggunakan kompetensi kognitif, efektif, dan psikomotorik. Dengan menggunakan rubrik untuk penilain kinerja yang digunakan oleh guru.

c. Penilaian Portofolio

Penilaian ini yaitu penilaian yang berkelajutan yang didasarkan pada kumpulan informasi yang menunjukkan perkembangan kemampuan peserta didik dalam satu periode. Informasi tersebut dapat berupa karya peserta didik dari proses pembelajaran yang dianggap terbaik. Penilaian portofolio adalah kumpulan karya peserta didik secara individual atau kelompok pada satu periode pembelajaran tertentu. Penilaian terutama dilakukan oleh guru meski dapat juga oleh peserta didik sendiri. Jadi tugas yang diberikan kepada siswa dalam penialain portofolio adalah tugas dalam Konteks kehidupan sehari-hari.

${ }^{22}$ Abdul majid, Penilaian Autentik Proses dan Hasil Belajar, 63.

${ }^{23}$ Abdul majid, Penilaian Autentik Proses dan Hasil Belajar, 64-65. 
Siswa diharapkan untuk mengerjakan tugas tersebut secara lebih kreatif, sehingga siswa memperoleh kebebasan dalam belajar. ${ }^{24}$

Pada penilain portofolio di MIN 6 Jember sering digunakan kepada siswa. Karena guru akan mengetahui perkembangan atau kemajuan belajar siswa misalnya: guru meminta untuk mengerjakan dan membuat puisi, gambar, surat dll.

d. Jurnal

Jurnal tulisan yang dibuat siswa untuk menunjukkan segala sesuatu yang telah dipelajari atau diperoleh dalam proses pembelajaran. ${ }^{25}$

Pada penilain jurnal biasanya guru di MIN 6 Jember guru meminta siswa untuk memnulis kembali materi yang sudah dipelajari untuk merangkumnya.

e. Penilaian Tertulis

Tes tulis berbentuk uraian atau esai menuntut peserta didik mamu mengingatkan, memahami, mengorganisasikan, menerapkan, menganalisis, menyintes, mengevaluasi pada materi yang sudah dipelajarinya. ${ }^{26}$

Biasanya guru di MIN 6 Jember itu dalam memberi penilaian tes tulis ini guru memberikan soal yang berbentuk pilihan ganda atau esai. Dan juga guru memberikan tugas itu bukan hanya benentuk seperti itu tetapi juga berbentuk mewarnai, menggambar, memberi tanda dan lain sebagainya.

Di MIN 6 Jember dari pemaparan yang berdasarkan teori penilaian pembelajaran tematik sudah sesuai dengan yang telah peneliti temukan dilapangan. Bahwa penilaian yang dilakukan guru di MIN 6 Jember menggunakan penilaian autentik dengan beberapa jenis penilain autentik yang dikaitkan dengan pengalaman siswa secara langsung.

Berdasarkan temuan-temuan yang peneliti yang dilakukan di Madrasah tersebut bahwa penerapan evaluasi Contextual Teaching and Learning (CTL) yang dilaksanakan di MIN 6 Jember sudah baik, dikarenakan guru kelas IV-B sudah menerapkan evaluasi pembelajaran yang membuat guru lebih mudah dalam menilai siswa. Pertama, Guru menggunakan tes untuk mengukur hasil belajar siswa, nantinya dalam setiap tes ini guru dapat mengetahui siswa-siswa yang sekiranya menonjol atau sebaliknya, maka pemberian tes pun guru dapat mengacu pada pemberian tes yang pertama. Agar pemberian tes sesuai dengan kondisi kognitif siswa.

\footnotetext{
${ }^{24}$ Abdul majid, Penilaian Autentik Proses dan Hasil Belajar,., 67.

${ }^{25}$ Abdul majid, Penilaian Autentik Proses dan Hasil Belajar, 67.

${ }^{26}$ Abdul majid, Penilaian Autentik Proses dan Hasil Belajar, 68.
} 
Temuan tersebut kemudian dijelaskankan dengan teori yang dikemukakan oleh Ahmad Syaiful Ulum Evaluasi hasil pembelajaran atau evalusi hasil belajar menggunakan tes untuk melakukan pengukuran hasil belajar sebagai prestasi belajar, dalam hal ini adalah pengusaan kompetensi oleh setiap siswa.

Berdasarkan temuan yang telah dijelaskan dengan teori tersebut dapat disimpulkan bahwa penerapan evaluasi Contextual Teaching and Learning (CTL) pada pembelajaran tematik kelas IV-B sudah baik dan dapat menjadi acuan guru dalam penilaian rapot di MIN 6 jember.

\section{KESIMPULAN}

Kesimpulan yang bisa diambil berdasarkan fokus penelitian, penyajian data dan analisis, serta pembahasan temuan penelitian dari Penerapan Contextual Teaching and Learning (CTL) pada Pembelajaran Tematik Kelas IV-B Madrasah Ibtidaiyah Negeri 6 Jember Tahun Pelajaran 2019/2020, yaitu penerapan perencanaan Contextual Teaching and Learning (CTL) pada pembelajaran tematik yaitu suatu perencanaan strategi pembelajaran dengan kontekstual (mengadirkan dunia nyata) pada siswa, sehingga siswa akan merasa senang dalam pembelajaran. Kesimpulan temuan penelian dalam penelitian ini yaitu penerapan perencanaan menggunkan CTL memudahkan guru dalam merancang perencanaan pembelajaran di kelas dan temuan kedua guru dapat membuat perencanaan yang sesuai dengan kondisi siswa sehingga dapat memberikan motivasi siswa dan lebih giat lagi belajar. Dan Penerapan pelaksanaan CTL pada pembelajaran tematik kelas IV-B di mulai dari pembukaan materi pelajaran, kegiatan inti, dan penutup, guru sudah melaksanakan dengan baik sesuai perencanaan pembelajaran. Kesimpulan yang diambil peneliti yaitu guru memberikan tugas praktek kepada siswa yang dapat membuat siswa lebih mempunyai semangat memulai dan mengakhiri pembelajaran, dan temuan selanjutnya siswa dapat membentuk jejaring atau dapat mengkomunikasikan apa yang ia ketahui dengan teman kelasnya. Dari temuan ini pelaksanaan CTL pada pembelajaran tematik kelas IV-B MIN 6 Jember sudah dilaksanakan dengan baik. Serta Penerapan evaluasi CTL pada pembelajaran tematik kelas IV-B MIN 6 Jember sudah sesuai dengan perencanaan pembelajaran dan juga dari pelaksanaan pembelajaran yang dilakukan oleh guru. Pelaksanaan yang sudah dilaksanakan dilakukan evaluasi untuk menilai siswa, temuan penelitian evaluasi pembelajarn dengan strategi CTL ini yaitu guru menggunakan tes untuk menilai siswa dari segi kognitif, afektif, dan psikomotorik. Guru menilai menggunakan tes ini untuk dapat 
mengukur siswa dalam segi penilain tersebut dan juga sebagai bahan dalam memberikan pelajaran pada siswa.

\section{SARAN}

Saran setelah diadakannya penelitian ini adalah, bagi mahasiswa Pendidikan Guru Madrasah Ibtidaiyah (PGMI) dapat mendiskusikan strategi yang efektif untuk pelajaran tematik, sehingga dapat merekomendasikannya kepada guru pelajaran salah satunya yaitu penerapan pembelajaran $C T L$. Bagi peneliti selanjutnya, hendaknya melakukan tindakan lebih dari penelian ini terlebih tentang penerapan $C T L$ pada pembelajaran tematik.

\section{CATATAN}

Catatan penulis dari penelitian ini yaitu penerapan $C T L$ pada pembelajaran tematik di kelas IV-B MIN 6 Jember menimbulkan pesan dan kesan, dari fokus penelitian penulis menemukan beberapa hal unik dari perencanaan, pelaksanaan, dan evaluasi pembelajarannya. Pada saat pelaksanaan pembelajaran dengan $C T L$ siswa memiliki antusias yang tinggi, yang sebelumnya pasif namun sudah telihat aktif dalam pembelajaran.dan juga penerapan $C T L$ ini lebih tepat bila digunakan dalam pembelajaran tematik.

\section{DAFTAR PUSTAKA}

\section{BUKU :}

Akbar, Sa'dun Dkk. 2017. Impelenmtasi Pembelajaran Tematik di SekolahDasar. Bandung:

Rosda Karya.

Almanshur, Fauzan dan Ghony, Djunaidi , M. 2017. Metode Penelitian kualitatif. Jogjakarta:

Ar-Ruzz Media.

Dolong, M. Jufri. 2016. Sudut Pandang Perencanaan dalam PengembanganPembelajaran.

Hamdayana, Jumanta. 2017. Model dan metode pembelajaran Kreatif danBerkarakter. Bogor:

Ghalia Indonesia.

Idi, Abdullah. 2011. Sosiologi Pendidikan (Individu Masyarakat, danPendidikan). Jakarta:

PT Raja Grafindo Persada.

Kunandar,Djahiri, 2007. Guru Profesional. Jakarta. PT Raja Grafindo Persada. 
Kurniasih, Imas. 2017. Lebih Memahami Konsep \& Proses Pembelajaran. Yogyakarta: Kata Pena.

Lailatul Usriyah, dkk. 2018. Dari pembelajaran Tematik Terpadu hinggapembelajaran literasi. Surabaya. IMTIYAZ.

Madjid, Abdul. 2014. Pembelajaran Tematik-Terpadu. Bandung:Remaja Rosdakarya. Mamik, Istuti ,Sri dan Sutirdjo. 2016. Tematik. Malang: Bayu Media Publishing. Mashudi. 2012. Strategi Pembelajaran di Perguruan Tinggi. Lumajang: LP3DI Press.

Matthew B. Miles, A, Michael Huberman, Jhonny Saldana, Qualitative Data analysis A Methods Sourcebook (3 rd edision)

Miles and Huberman . 2014. Analisis Data Kualitatif . Jakarta: UI- Press.

Moleong, Lexy J. 2017. Metode Penelitian Kualitatif. Bandung: Remaja Rosdakarya.

Mukni'ah, 2016. Perencanan Pembelajaran. Jember: IAIN Jember Press.

Rahayu, Trisna, Ega, Strategi Pembelajaran Pendidikan Jasmani.

Rivai, Ahmad,\&Sudjana, Nina. 2001. Media Pengajaran. Bandung: Sinar Baru Algesindo.

Rusman. 2015. Pembelajaran Tematik Terpadu. Jakarta: Rajawali Press.

Sahlan,Moh. 2013.Evaluasi Pembelajaran: Panduan Praktis Bagi Pendidik dan Calon Pendidik. Jember: Stain Jember Press.

Sani, Abdullah, Ridwan. 2013. Inovasi Pembelajaran. Jakarta: Bumi Aksara.

Sholihin, Aris. 2014. 68 Model Pembelajaran Inovatif dalam Kurikulum 2013. Yogyakarta: ARRUZZ MEDIA.

Sugiyono, 2017. Metode Penelitian Kualitatif. Bandung: Alfabeta.

Poerwati, Endah, Loeloek. 2013. Panduan memahami Kerikurulum 2013. Jakarta: Pretasi pustaka.

\section{SKRIPSI, TESIS, DISERASI DAN LAPORAN PENELITIAN :}

Fifik Endah Wahyuni. 2013. "Penerapan Contekstual Teaching and Learning (CTL) melalui metode Eksperimen dalam pembelajaran IPA terhadap Hasil Belajar siswa kelas V SDN Kesilir 1 Wuluhan Jember. Skripsi Fakultas keguruan dan ilmu pendidikan Universitas Jember.

Ulfianita. 2018. "Implementasi Contekstual Teaching and Learning pada pembelajaran Tematik kelas III di Madrasah Ibtidaiyah Negeri 1 jember Tahun Pelajaran 2017-2018”. Skripsi Fakultas Tarbiyah IAIN Jember. 


\section{ARTIKEL DAN:}

Dyah, Palupining, Agun R. 2012.Pelaksanaan Pembelajaran Dan Hasil Belajar Siswa dalam Pembelajaran Busana Wanita Kelas Xi Busana 4 Di SMKN 4 Yogyakarta. Yogyakarta: Universitas Negeri Yogyakarta.

Ali Nurhadi. 2014. "Penerapan Contekstual Teaching and Learning (CTL) dalam Meningkatkan

Pembelajaran Pendidikan Agama Islam di SDN 2 Sumberanyar kecamatan Wongserejo kabupaten Banyuwangi Tahun pelajaran 2013/2014".Skripsi Fakultas Tarbiyah IAIN Jember.

Mawardi, Annisa Tiara Widya Saputri. Vol. IV No. 2 Juli 2017. "PENGEMBANGAN DESAIN

PEMBELAJARAN TEMATIK INTEGRATIF BERBASIS PENDEKATAN CONTEXTUAL TEACHING AND LEARNING (CTL) KELAS 4 SEKOLAH DASAR” PGSD FKIP Universitas Kristen Satya Wacana, Jurnal Ilmiah "Pendidikan Dasar"

Ulum, Syaiful, Ahmad. 2017. Implementasi Evaluasi Pembelajaran Pendidikan Agama Islam Berbasis Komputer Based Test. Malang: UIN Maulana Malik Ibrahim.

\section{AL-QUR'AN DAN PERUNDANG-UNDANGAN :}

DEPAG RI. 1986. Al-Qur'an dan terjemahannya. Bandung : Gema Risalah.

PMA no 90 tahun 2013 tentang Penyelenggaraan Pendidikan Madrasah.

PP No No. 32 Tahun 2013.Kegiatan Pembelajaran di SD/MI.

UU RI no 20 tahun 2003 tentang Sistem Pendidikan Nasional 